\title{
MBA Program Revision and the Impact on the CIS Option
}

\author{
Doris G. Duncan \\ California State University, East Bay \\ (formerly California State University, Hayward) \\ Hayward, California USA
}

doris.duncan@csueastbay.edu

\begin{abstract}
Leaders at California State University, East Bay, in the College of Business and Economics decided to review and revise the MBA Program prior to the upcoming accreditation visit. The outcome was a program with fewer foundation courses, more core course requirements and fewer options (sometimes called areas of specialization or tracks). The number of foundation courses was reduced from nine to three, the number of required core courses was increased from three to nine and the number of specialized option courses was reduced from about five (depending on the option) to three. The number of options was reduced from 16 to 8 . The Computer Information Systems option was revised and named Information Technology Management. CIS/ITM survived the reduction in options - for now.
\end{abstract}

Keywords: MBA revision, MBA curriculum, MIS graduate curriculum, CIS graduate curriculum, ITM graduate curriculum

\section{Introduction}

California State University, East Bay is a mid-sized university located in the San Francisco Bay Area. It has enrollment of about 14000 (9000 full time equivalent) students. It was established in 1957 and the College of Business and Economics (CBE) shortly after that. By 1973 the CBE achieved AACSB (Association to Advance Collegiate Schools of Business) accreditation and has maintained it ever since, the most recent renewal being in February, 2009. The normal AACSB accreditation renewal cycle is every five years.

As part of preparing for maintenance of accreditation, California State University, East Bay leadership decided in fall 2007 to evaluate and update its MBA program. Several people participated in the evaluation process including the new Dean of CBE, the five-member curriculum committee, the Director of MBA Programs and four Department Chairs. Feedback was also sought from

Material published as part of this publication, either on-line or in print, is copyrighted by the Informing Science Institute. Permission to make digital or paper copy of part or all of these works for personal or classroom use is granted without fee provided that the copies are not made or distributed for profit or commercial advantage AND that copies 1) bear this notice in full and 2) give the full citation on the first page. It is permissible to abstract these works so long as credit is given. To copy in all other cases or to republish or to post on a server or to redistribute to lists requires specific permission and payment of a fee. Contact 0HPublisher@InformingScience.org to request redistribution permission. faculty, students and employers. The revision of this part-time, evening MBA program that many of the more than 600 students enrolled are able to complete in two years was a major focus for an entire academic year, as shown in Figure 1 . 


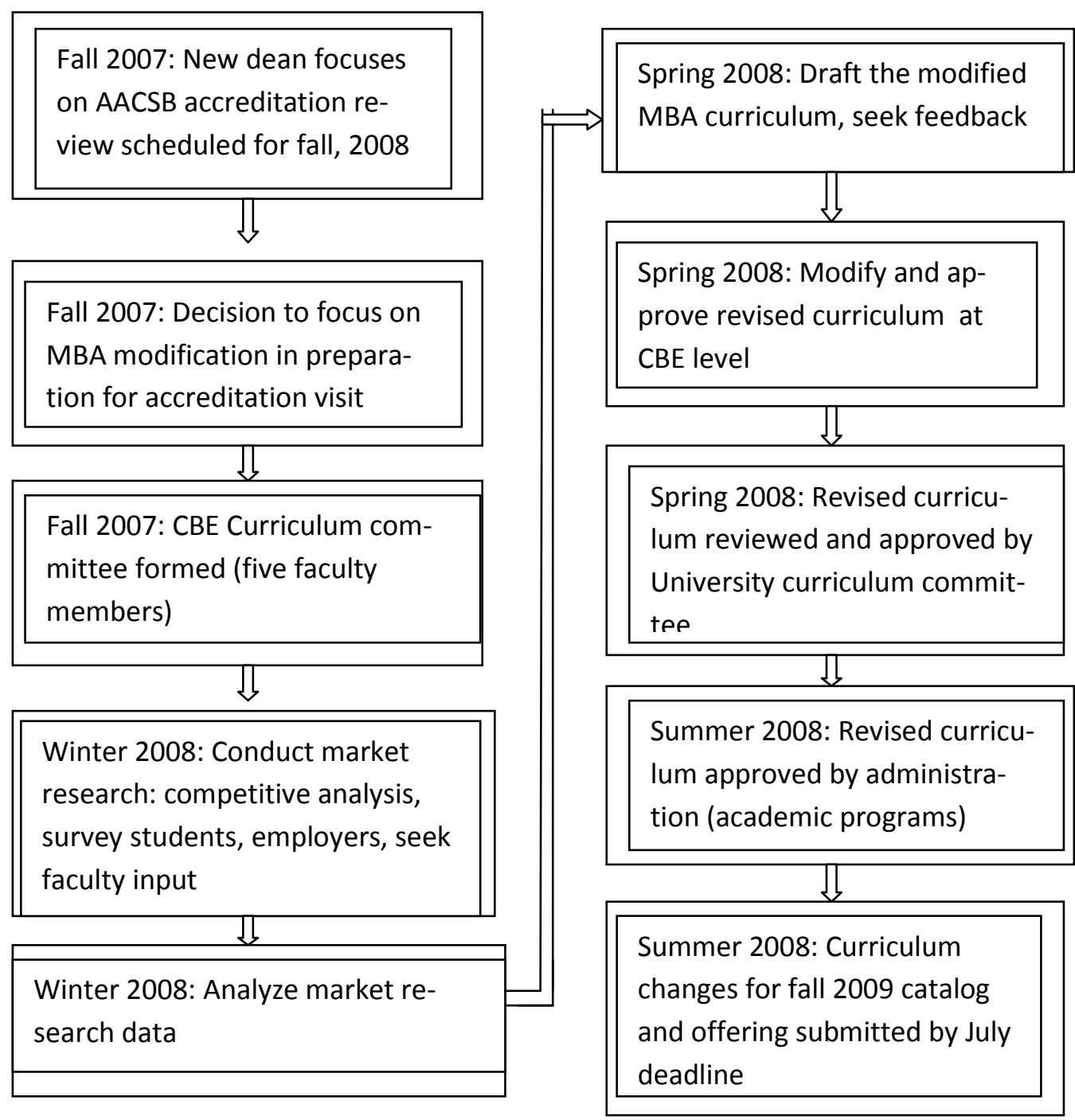

Figure 1: Decision Flow for MBA Revision at California State University, East Bay

The primary focus was on what topics should be included in the core requirements and how much emphasis should be placed on specialized options. Options that had small enrollment or that were experiencing declining enrollments, for example CIS, were also closely scrutinized as part of the MBA program review.

\section{Background and Literature Review}

We relied more on primary market research than on any review of the literature insofar as whether and how to modify the MBA Program at California State University, East Bay. Once the author undertook a literature review, she identified some insightful remarks about information systems as a discipline.

A good starting point is to define terminology used. T. Grandon Gill, the Editor-in-Chief of the Informing Science Journal, in 2009 refers to Eli Cohen's definition of the informing process as: 
1) providing a specific clientele with information, 2) in a form, format, and schedule, 3) that maximizes its effectiveness (Gill, 2009).

Cohen describes "Informing Science" as an evolving transdiscipline that studies issues in informing clients (Cohen, 2009). In discussing his philosophy of informing science, Cohen addresses how terms that mean different things get used interchangeably, for example, "Computer Science", "Management Information Systems", "Information Science" as well as "Intelligent Services" (Cohen, 2009). Perhaps additional terms as "Computer Information Systems," "Information Technology Management" and "Business Information Systems" need to be added to this growing list. Cohen also distinguishes between broad "lantern" and focused "laser" forms of research.

In the case of the MBA Program at California State University, East Bay, stakeholders include students, faculty, administrators, perhaps alumni and employers, and prospective stakeholders. The MBA is intended to be a general degree comprised of a broad range of business topics on management, marketing, accounting, finance, operations, supply chain, economics, governmental regulation, technology, globalization, etc. Compared with an MS in Information Technology Program, the MBA is more interdisciplinary and less specialized. Furthermore, the 2009 revised MBA places more emphasis on general business and interpersonal skills and less emphasis on the options/areas of specialization.

Consistent with this broad focus is the revision of the CIS option to ITM which suggests a shift from adapting computer information systems technology to the user toward the management of the information technology function (hardware, software, networks, and data). Systems analysts and others who help adapt the technology to user needs normally work within the information technology department.

The extent of discussion and debate regarding what courses to include or exclude in the required set of fundamental (prerequisite) or core courses varied substantially depending on the course/topic. The information systems topic encountered more scrutiny than most others. This may not be unusual. David Avison wrote that there is continual pressure at many universities to re-examine the MBA curriculum, with particular emphasis on reducing the compulsory core portion. One of the courses that may be taken out over time is information systems. Avison then proceeded to present a case that information systems faculty can use to defend keeping information systems in the core (Avison, 2003). Among the universities with IS in the MBA core are: Harvard, Berkeley, Stanford, Columbia, Cornell, and London Business School. At California State University, East Bay we also decided to retain IS/ITM 6015 Information Systems Development and Management as a fundamental course. Students have the choice of testing out of all three fundamental courses: Financial Accounting, Data Analysis and Decision Making, and Information Systems Development and Management.

As the MBA revision process at California State University, East Bay unfolded, it became increasingly obvious how much our MBA program was in need of updating, perhaps continuous updating. As Robert Winter succinctly explained, in many industries, business structures once considered stable for decades have undergone enormous change, leading to complex and dramatic transformation needs in many organizations (Winter, 2002). For example, due to deregulation, outsourcing, business networking and the Internet, retail banking has changed more in the past few years than an entire generation before. This has tremendous implications for what the content of MBA programs should be. 


\section{Curriculum Modification}

\section{Mission, Objectives, and Learning Outcomes}

At a $\mathrm{CBE}$ faculty retreat, the $\mathrm{CBE}$ revised its mission as follows:

The mission of the College of Business and Economics is to prepare students to make ethical choices and succeed in a dynamic business environment shaped by the challenges of a competitive global economy, emerging technologies, and diverse stakeholders. All CBE programs are accredited by the Association to Advance Collegiate Schools of Business International (AACSB).

The MBA program objectives and student learning outcomes were revised to be consistent with the current mission:

\section{Objectives:}

1. The MBA program will prepare students in important management skills.

2. Students graduating from the MBA program will experience positive career outcomes including salary increases, opportunities for promotion, and advancement into management positions as a result of their experiences in the program.

\section{Student learning outcomes:}

Students graduating with an M.B.A. from this University will have achieved the following:

1. Leadership and Teamwork. Each graduate will be able to analyze how to use highperformance management behaviors to lead a team task that results in effective team performance.

2. Integrative and Strategic Perspective. Each graduate will integrate functional areas of business knowledge to generate a strategic business plan.

3. Global Perspective. Each student will analyze the global business factors impacting current business issues, and evaluate the effects of these factors on specific management situations.

4. Communication. Each student will communicate a complex business issue in a coherent written statement and oral presentation.

\section{Competitive Analysis}

Next, we conducted a competitive and comparative analysis by surveying existing MBA programs 1) in our geographic proximity - San Francisco Bay area, both public and private universities; 2) the California State University System; 3) research institutions in the San Francisco Bay area; 4) peer institutions identified; and 5) aspirant institutions. The focus was on admission requirements, proficiency requirements, foundation work, options offered, and required courses vs. elective courses. Later a survey of students was conducted. Feedback from current and prospective employers was also sought. The "old" MBA program is summarized in Tables 1 and 3. 


\section{Table 1: Existing MBA at CALIFORNIA STATE UNIVERSITY, EAST BAY \\ -Before Modification in 2009}

(Source: California State University East Bay Catalog 2008-2010)

\section{Proficiency course requirements:}

Math - differential calculus

Introductory Statistics

Writing skills requirement

\section{Foundation course requirements:}

Graduate Introduction to Financial Accounting

Graduate Introduction to Managerial Accounting

Graduate Introduction to Computer Information Systems

Graduate Introduction to Economics for Managers

Graduate Introduction to Financial Decisions

Graduate Introduction to Quantitative Methods

Business and Society

Graduate Introduction to Organization and Management

Managerial Marketing Theory and Practice

\section{Graduate core course requirements:}

Seminar in Financial Management

Operations Management

Interpersonal skills course (choose from a list)

\section{Capstone course experience:}

Seminar in Strategic Management or Entrepreneurship Practicum

Elective courses: usually four to five courses, depending on which option student pursues

Note: an additional international course requirement can be met by a course that also satisfies an option requirement. 


\section{Table 2: Modified MBA at CALIFORNIA STATE UNIVERSITY, EAST BAY -- Effective Fall 2009}

(Source: California State University East Bay Catalog 2010-2012)

\section{Proficiency course requirements:}

Introductory Mathematics

Introductory Statistics

Writing skills requirement

\section{Fundamental (foundation) course requirements:}

Financial Accounting Information Systems Development and Management

Data Analysis and Decision Modeling for Managers

\section{Graduate core course requirements:}

Globalization, Innovation and Sustainability

Managerial Communication

Managerial Accounting

Economics for Managers in a Global Society

Corporate Financial Management

Marketing Management

Business, Government, and Society

Operations and Supply Chain Management

Executive Leadership

\section{Capstone Experience:}

Seminar in Strategic Management or Entrepreneurship Practicum

\section{Elective courses:}

Student takes 3 electives courses to meet option or general MBA requirement

\section{Emergence of Updated MBA}

From the competitive analysis and surveys, we found our program at California State University, East Bay placed more emphasis on foundation/prerequisite work and options than on a required core. This influenced the resulting MBA modification shown in Tables 2 and 4. As part of the restructuring, the number of foundation courses decreased from nine to three, the number of required core courses increased from three to nine, the capstone experience remained at one course, the mathematics proficiency course was changed from differential calculus to college algebra. The number of options to choose from was reduced by half, from sixteen down to eight. While 
more emphasis is placed on the common core requirements, less emphasis is placed on specialization. These changes, including the switch from calculus to college algebra, were made to make our MBA program more competitive and cost effective. The revised MBA was first offered in fall 2009.

\section{Table 3: 16 Existing MBA Options/areas of specialization at CALIFORNIA STATE UNIVERSITY, EAST BAY to Choose from} Before Modification in 2009

(Source: California State University East Bay Catalog 2008-2010)

Accounting

Business Economics

Computer Information Systems

E-Business

Entrepreneurship

Executive

Finance

Human Resource Management

International Business

Management

Marketing Management

Operations and Materials Management

Strategic Management

Supply Chain Management

Taxation

Telecommunications Management

\section{Table 4: 8 Options/areas of specialization to Choose from in Modified MBA at CALIFORNIA STATE UNIVERSITY, EAST BAY}

Effective Fall 2009

(Source: California State University East Bay Catalog 2010-2012)

Entrepreneurship

Finance

Human Resources and Organizational Behavior

Information Technology Management

Marketing Management

Operations and Supply Chain Management

Strategy and International Business

No option - General MBA 


\section{What Became of the Computer Information Systems MBA Component?}

\section{Generalization of the MBA Program}

By comparing Table 1 with Table 2, it is evident that Computer Information Systems (CIS) does not appear on Table 2 as a foundation course. However, Information Technology Management does. The same holds true when comparing Tables 3 and 4. Computer Information Systems is one of sixteen options listed in the "old" MBA program. Information Technology Management is one of eight options to choose from in the revised MBA program. About a year prior to overhauling the MBA, we modified the CIS program at both the undergraduate and graduate level and renamed it Information Technology Management.

\section{Emergence of MBA/ITM Option}

At many Universities, including California State University, East Bay enrollments in the CIS option, and programs of a similar name, have gradually declined since the peak in year 2001 or so. It became obvious that we needed to do something to reverse this trend or discontinue the program. By 2006 the CIS and other business faculty began talking about modifying the CIS option and promoting it more. Several people participated and what emerged was a "new" ITM option comprised of 3 courses (12 quarter units) to "replace" the CIS option which consisted of 7 courses ( 28 units) but two of which had to be outside the field of CIS. By comparing the two programs summarized in Table 5, it is apparent that the ITM option is more about business and management and less about technology than the CIS option. Early indicators suggest that the enrollment decline has leveled off and that there may be a gradual upward trend. It will take more time to ascertain whether the trend is upward. If not, the ITM option may become vulnerable to discontinuation just as have other programs.

\section{Conclusion}

There was some discussion of eliminating entirely the CIS, now ITM option, due to declining enrollments. However, the faculty members who normally teach ITM courses, including the MBA Director, were able to save the area of CIS, now ITM, in anticipation of future enrollment growth. So far we have a very modest increase in ITM enrollments since restructuring. Faculty must work hard at attracting more students to the ITM option or it may be eliminated as has been the case at other institutions. Now that MBA students at California State University, East Bay have just eight options (including the general MBA) to choose from, the author expects enrollments will grow in all eight options. However, in the event that ITM enrollments do not sufficiently increase and the program is eliminated, ITM faculty members will most likely still have a foundation course to teach at both the undergraduate level and in the MBA program. Only time will tell how well CIS and ITM programs will evolve and succeed in the future. A survey of alumni and employers would provide additional insights. 


\section{Table 5: Comparison of former CIS and new ITM options in MBA Program at CALIFORNIA STATE UNIVERSITY, EAST BAY}

\section{Former Computer Information Systems Option (28 quarter units)}

(Source: California State University East Bay Catalog 2006 - 2008)

\section{$\underline{\text { Prerequisite courses }}$}

CIS 3275 Object Oriented Programming or CS (Computer Science) 3340 Intro to Object Oriented Programming and Design or any advisor approved object-oriented programming language taken during the last three years.

CIS 3281 Systems Analysis and Design

$\underline{\text { Required courses }}$ ( 4 courses, 16 units):

CIS 6270 Advanced Study of Computer Information Systems

CIS 6274 Data Base Theory and Administration

CIS 6275 Decision Support and Expert Systems

CIS 6276 Data and Voice Communications

Electives within Computer Information Systems (4 units):

Select one graduate level CIS or TC (Telecommunications) course that is not listed as required.

Electives outside Computer information Systems (8 units):

Select two courses (8 units) of 6100-6999 level College of Business and Economics courses outside of CIS or any other department-approved graduate-level course (including Mathematics and Computer Science) outside of CIS. Management 6110 Business and Economic Forecasting is strongly recommended as one of these elective courses.

New Information Technology Management Option (12 quarter units, also called the "modified" CIS option) (Source: California State University East Bay Catalog 2008-2010)

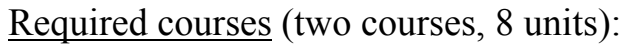

ITM 6271 Data Base Management and applications

ITM 6273 Business Intelligence and Knowledge Management

Elective within ITM: Choose one of the following courses (4 units):

ITM 6130 Enterprise Management Systems

ITM 6278 E-Business Systems Development

MGMT 6155 Applied Project Management 


\section{References}

Avison, D. (2003). Information systems in the MBA curriculum: An international perspective. Communications of the Association for Information Systems, 11, 1-23. Retrieved on March 2, 2009 from http://cais.isworld.org/articles/11-6/article.pdf

Cohen, E. (2009). A philosophy of informing science. Informing Science: The International Journal of Emerging Transdiscipline, 12, 1-14. Retrieved on March 2, 2009 from http://www.inform.nu/Articles/Vol12/ISJv12p001-015Cohen399.pdf .

Gill, T. G. (2009). An open letter to the informing science community. Informing Science: the International Journal of an Emerging Transdiscipline, 12, v-x. Retrieved on March 2, 2009 from http://inform.nu/Articles/Vol12/ISJv12pv-xGill.pdf

California State University East Bay Catalog 2006-2008. West Sacramento, CA: Delta Web Printing, Inc.

California State University East Bay Catalog 2008-2010. West Sacramento, CA: Delta Web Printing, Inc.

California State University East Bay Catalog. 2010-2012. West Sacramento, CA: Delta Web Printing, Inc.

Winter, R. (2002). An executive MBA program in business engineering: a curriculum focusing on change. Journal of Information Technology Education, 1(4), 279-288. Retrieved on March 2, 2009 from http://jite.org/documents/Vol1/v1n4p279-288.pdf

\section{Biography}

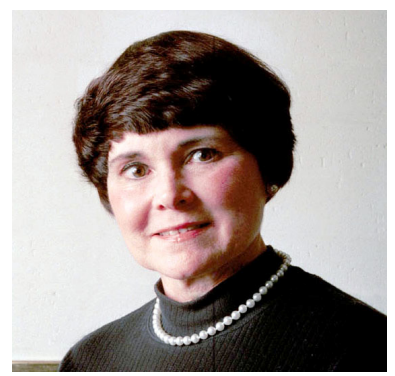

Dr. Doris Duncan, CCP, CSP, CDP, CDE, is a Professor of Computer Information Systems and past Director of MBA Programs (20062008) at California State University, East Bay, USA. Extensive service to CSUEB includes serving as the CIS area coordinator and graduate advisor for CIS and e-business programs. Duncan was a Visiting Professor of Information Systems at the University of Washington, Seattle, 1997-98 and the Program Director of Information Systems at Golden Gate University, San Francisco, 1982-83. Her thirty plus years of experience in information technology include communications consultant and marketing manager for AT\&T, program director for Input, Inc., and member of senior management consulting staff at Quantum Science Corporation. She has had consulting engagements with several businesses, including Dialog Information Services, Pacific Bell Telephone Co., Valicert, Golden Gate University, Prentice Hall, McGraw-Hill Book Co. Dr. Duncan authored a book, Computers and Remote Computing Services, and has published about 70 refereed journal articles and conference presentations. She is also a frequent speaker before professional groups. Duncan is past president of the Data Processing Management Association, San Francisco Chapter, and has served on the Board of Directors of several professional societies, including DPMA, the DPMA Special Interest Group in Education, and the Institute for Certification of Computer Professionals Education Foundation. Duncan served as the Associate Editor for the Journal of Informatics Education Research and has served on the editorial review board for the JIER and Journal of Information Systems Education, Journal of Information Technology Education and as a reviewer for many textbooks and conference proceedings. Duncan was selected "Computer Educator of the Year" in 1997 by the International Association of Computer Information System, served as a Fulbright Specialist in 2009, and is listed in over 30 Who's Who publications, including Who's Who in America and Who's Who in the World. 